\title{
Non-Financial Performance of Micro Credit Entrepreneurs: Does Personal Religious Values Matters?
}

\author{
A. H. Fatimah-Salwa ${ }^{1,2}$, A. Mohamad-Azahari ${ }^{3} \&$ B. Joni-Tamkin ${ }^{1}$ \\ ${ }^{1}$ Academy of Islamic Studies, University of Malaya, Kuala Lumpur, Malaysia \\ ${ }^{2}$ Faculty of Management and Economics, Universiti Pendidikan Sultan Idris, Tanjung Malim, Perak, Malaysia \\ ${ }^{3}$ Department of Shariah Compliance, National Cooperative Force Malaysia Berhad, Selangor, Malaysia \\ Correspondence: A. H. Fatimah-Salwa, Department of Economics, Faculty of Management and Economics, \\ Universiti Pendidikan Sultan Idris, 35900 Tanjung Malim, Perak, Malaysia. E-mail: salhadi2009@yahoo.com
}

Received: April 14, 2013

Accepted: May 10, $2013 \quad$ Online Published: May 21, 2013

doi:10.5539/ijef.v5n6p34

URL: http://dx.doi.org/10.5539/ijef.v5n6p34

\begin{abstract}
Two main objectives namely motivate this study: Firstly, to explore the profile of successful entrepreneurs who are recipient of micro credit financing from both Lembaga Zakat Selangor (LZS) and Amanah Ikhtiar Malaysia (AIM). The second objective intends to empirically investigate the possible relationship between the personal religious values and non-financial performance of the entrepreneurs. The microcredit entrepreneurs in Selangor that have been into entrepreneurial activities for at least five years are the targeted respondents. The numbers of respondents were determined through the snow ball sampling technique. The dependent variable in this study is thus represented by the non-financial performance indicator while the independent variables consist of 24 items that serve as indicator for the personal religious values. The result of multiple regression analysis (stepwise method) indicated revealed significant relationship of all the factors to the non-financial performance of LZS and AIM with the exception of truth and right variable. Based on the result, some recommendations were proposed together with the limitation of study that suggest possible prospect for further research.
\end{abstract}

Keywords: entrepreneurship, non-financial, micro credit, performance, personal religious values

\section{Introduction}

Currently, micro credit is considered as one of the prominent tool to alleviate poverty and has been widely used in most of the developing countries including Malaysia, Indonesia, Bangladesh, Philippines and others for such purpose (Park \&Ren, 2001; Afrane, 2002; Khander, 2003; Rahman et al.,2009). Consequently, many institutions such as banks, private trust body, institution of zakat and host of other institutions came up with various model of micro credit financing designed especially to the poor in Malaysia. In term of participation, the majority of the participants are Muslims.

Accordingly, Amanah Ikhtiar Malaysia (AIM) is recognized as the pioneer and the most successful institution regarding the offering of such financing. Up to March 2013, the total amount of financing disbursed by Amanah Ikhtiar Malaysia (AIM) is estimated at RM 8.2 billion (RM 8,201,128,533) with a repayment rate of about 99.36 percent (Amanah Ikhtiar Malaysia, 2013). In fact, AIM has achieved a remarkable repayment due to its unique method of managing risk.

The group based model result to social pressure that motivates client members to avoid defaulting on their loans. Besides that, the set up of the weekly meeting serves as a mechanism by itself to make sure that members attend and subscribe their weekly payments. In the event that a group member fails to repay, other members in the group will bear the responsibility by raising funds to help the defaulter. In addition, the AIM personnel also make field trips to monitor member projects (Norma and Jarita, 2010). All these mechanism thus help to minimize default rate and serve as an effective strategy to manage the associated default risk.

Similarly, Lembaga Zakat Selangor (LZS), a non-profit organization also renders such financing particularly to improve the economy of the downtrodden and poor Muslim in the society. The source of fund is from the collection of zakat paid by the zakat payers while the amount of disbursement is greatly depended on the type of business together with the performance of the recipients. The financing offer by LZS is tremendously free of charge intentionally designed to help the less privileged and poor people in line with the spirit of brotherhood 
among the Muslims.

Instead of disbursing the micro credit financing in the form of physical money, LZS applies the unique mechanism whereby they provide business capital based on two techniques. The first technique is to disburse the capital assistance which is vastly depended on the application made by the recipients to operate their business. Alternatively, such financing is also offered to the selected viable businesses with high potential of success is considered as another applied technique of distribution. However, the selection based on the latter very much depends on the decision of LZS management (Hamdino Hamdan, Pazim \& Wan Sabri, 2012). In term of performance, the percentage of successful entrepreneurs under this program is slightly low compared to that of Amanah Ikhtiar Malaysia (AIM). As indicated, it recorded less than 30 percent in term of performance of the entrepreneurs (Lembaga Zakat Selangor, 2013).

At a glance, zakat is declared as the third of five 'pillars' of Islam, and it is payable on the assets such as gold, livestock, agricultural products and funds. Consistent with the brotherhood concept in Islam, the requirement to pay zakat is also closely related with the idea of equality and justice that lies under the Islamic principles. The main purpose of zakat is to support the less fortunate group in the society such as the poor, the needy, the wayfarer or those that are heavily indebted with the hope that this group of people will at least meet their basic needs and uplifted from absolute poverty. It is generally believed that zakat plays an important role in term of economy, moral and social aspect of a society (Farah Aida, Rashidah \& Normah, 2012).

Since all LZS entrepreneurs and majority of AIM entrepreneurs are Muslim, there are several approaches regarding training and various talks are conducted by both institutions purposely to enhance the understanding of religion. Such understanding is deemed vital because it can create or enhance the religious personal values of the entrepreneurs which later on can influence the strategies they adopt in business operation and ultimately make huge impact on the performance of their business (Kotey \& Meredith, 1997). As a result of it, the awareness of the entrepreneurs toward the importance of religion especially in conducting the entrepreneurial activities is uplifted from time to time.

Based on the empirical evidence, many factors are identified to be associated with the success of micro credit entrepreneurs. Some of the studies linked entrepreneurial success to the characteristics of entrepreneurs (Markman \& Baron, 2003), micro credit financing (Kuzilwa, 2005, Carter \& Shaw, 2006; Hietalahti \& Linden, 2006), government assistants (Sarder et al., 1997; Bowen \& De Clercq, 2008; Minniti, 2008), education (Thapa, 2007; Bhutta et al., 2008; Wijewardena et al., 2008), previous experiences (Alowaihan, 2004; Raduan et al., 2006; Syed Wajahat, 2011; Muhammad Amjad Saleem, 2012) and some other factors.

However, one key factor that has generated a lot of debate among scholars in relation to the success of the entrepreneur is religious attribute of the entrepreneurs. According to Clark \& Dawson (1996), the personal religiousness has been described as an apt starting point for finding the differences in moral judgment based on the fact that, religious ideology lay much emphasize on individual's decision regarding what is right and wrong.

Among the extant literatures that explore the relationship between performance of entrepreneurship and the religious attribute of the entrepreneurs include (Cunningham \& Lischeron, 1991; Kotey \& Meredith, 1997; Gadenne, 1998; Peterson et al., 2010) who indicated significant relation between these two variables while others studies such as (Rohaizat \& Suzilawati, 2001) suggest no significance relationship between religious factors and the performance of the entrepreneurs. In line with these arguments, a study that identifies the existence of relationship between personal religious values and the performance of the entrepreneurs based on the two mentioned institutions (Amanah Ikhtiar Malaysia and Lembaga Zakat Selangor) is deemed necessary and keep arousing the interest of the researcher.

This study is therefore aimed at filling this gap by exploring the profile of the successful entrepreneurs that are recipient of the micro credit financing from the two different institutions namely: Lembaga Zakat Selangor (LZS) and Amanah Ikhtiar Malaysia (AIM). Furthermore, the study also aims to empirically identify the possible relationship between the personal religious values and non-financial performance of the entrepreneurs. As such, the remaining of this paper is organized as follow: the literature review is discussed in section two which is followed by the data and methodology that is discussed in section three. After that, the empirical finding is presented in section four. Recommendation and limitation of the study are therefore discussed in the last part.

\section{Literature Review}

\subsection{Performance of Entrepreneurs}

Rhodes \& Butler (2004) categorized the measurement of performance into two methods namely objective (financial) and subjective (non-financial) measurement. Several dimension are used to represent the financial 
performance among which are asset owned (Norma \& Jarita, 2010), income (Haber \& Reichel, 2005), return on investment (Gadenne, 1998), return on asset (Masuo et al., 2001) and so on.

Conversely, Kenji (2002) attack the determination of performance based on this objective method which is considered as a traditional technique of assessment. In view of that, some rationale behind it where indicated. Some of the justification include: the difficulty of getting the accurate information of financial performance (Garengo et al., 2005), problem of tracing improper financial record (Zinger et al., 2001), the perception of financial performance as private and confidential which cannot be revealed especially to the outsider (Rhodes \& Butler, 2004) and many more.

Alternatively, Murphy et al. (1996) propose the subjective method of assessing the performance of entrepreneurs. According to Harada (2003) and Dafna (2008), this method is better than the earlier method since the scope of assessment is wider and more applicable especially to the entrepreneurs who are involved in the small and medium enterprises. In line with this, the current study thus employs the subjective approach to assess the performance of entrepreneurs by following the work of scholars such as Dess \& Robinson (1984). As indicated, this method is has been linked with high reliability, validity rates and potential ability to precisely reflect the firm's objective performance.

\subsection{The Personal Religious Values and Performance}

According to Chusmir \& Koberg (1988) and Scheepers \& Frans (1998), the religious factor has been suggested to have the strongest factor that influences the morale of an individual. This thus implies that, religiosity play an important role towards individual ethical level. It means, an individual with higher level of religiosity is expected to be more ethical (Hunt \& Vitell, 1986). In their own view, Kotey \& Meredith (1997), the personal religious values has high potential to influence the performance of entrepreneurs since it can positively affect the characteristics of individual. Among the values expected of such individuals are: discipline (Sagie, 1993), accountable (Kotey \& Meredith, 1997), honest (Kriger \& Hanson, 1999; Pollitt, 2004; Zafir \&Fazilah, 2011) and many more. In the Islamic point of view, all these values also considered as important values that are expected from entrepreneurs (Siddiqui, 1997).

Specifically, Imam al-Ghazali (1998) emphasized several values that are crucial to Muslim entrepreneurs. Among them are: first, the intention of doing entrepreneurial activities should be aimed at obtaining Allah's pleasure; second, the entrepreneurial activities must be lawful; third, the decision of producing goods and services must be directed at fulfilling the obligation of Fardu Kifayah, which is to achieve the need of Muslim society; fourth, high priority should be given to the religion obligation; fifth, the responsibilities to themselves and the family must be observe even though they are encouraged to be hard working; sixth, they are forbidden from compromising with unlawful or non-transparent things in any of their conducts; seventh, the discussion and self-reflection should take place in their life to be the better person.

In support of the impact of religiosity, Cullen \& Parboteeah (2008) noted that, these noble values can be implemented regardless of the demographic and cultural background in order to be success as entrepreneur. Machan (1999) further highlight the important of these values to the entrepreneurs. The absent of religiosity element can potentially harm other parties in the transaction among who are: customers, consumers, competitor and many others. As a result, it can affect the whole system in the country. For the case of Malaysia, very limited number of studies that explore the possible relationship between the religious values and performance of entrepreneurs exist in the literatures. For example, the study conducted by Zafir \& Fazilah (2011) came to the conclusion of the existence of significant relationship between the successes of the entrepreneurs with their religious value.

On the other hand, studies conducted by Rohaizat \& Suzilawati (2001) revealed insignificant relationship between entrepreneur success and religiosity based on the individual construct and opposite outcome if all of them were been grouped. Overall, they came to conclusion that, low connection exist between these two factors. As Malaysian society increasingly indicated awareness and importance towards the religious values, this study is motivated to explore the relationship between personal religious values of the entrepreneur and their performance.

\section{Data and Methodology}

\subsection{Sampling Procedures and Instrument}

The respondents of this study constitute only the successful entrepreneurs who are recipient of the micro credit financing from two different institutions, to be exact are: Lembaga Zakat Selangor (LZS) and Amanah Ikhtiar Malaysia (AIM). As indicated, the former is recorded the lowest rate of successful entrepreneurs (less than 30 
percent) while the latter is recorded impressive performance (more than 90 percent) among the micro credit providers in Malaysia. Even though they are different in term of performance, since the majority of them are Muslims, both sides of entrepreneurs obtain appropriated training and speech from respective institutions particularly to improve the understanding of religion which later can be applied in the practice of entrepreneurial activities.

The collection of data for this study is conducted from January until March 2013. Besides that, the targeted respondents for this study are those entrepreneurs located in Selangor and who have been into entrepreneurial activities for at least five years. The absence of information about the respondent necessitates the choice of snow ball sampling technique in order to obtain adequate representation. Consequently, 337 respondents were selected in this study comprises 137 respondents from LZS and 202 respondents from AIM.

\subsection{The Measurement of Variables}

Following the work of Boohene \& Boachie-Mensah (2009), this study employs the non-financial performance indicators which consist of 11 items as the dependent variable. The combination of non-financial performance items take into consideration the widely used non-financial measurement introduced by Kotey \& Meredith (1997) and Gadenne (1998). Among them are: increased in sales revenue, business stability, profit maximization, organizational growth, industry leadership, increased productivity, lower cost of production, increased personal income to look after family, job creation, community development contribution and flexibility in combining family and work. The respondents are assessed based on the Semantic Differential Scale as suggested by Kolodinsky (1999): (1: very dissatisfied, 2: dissatisfied, 3: neutral, 4: satisfied, 5: very satisfied).

For the personal religious values, all items are adopted from the usable and factorable items which have been proposed by Rohaizat \& Suzilawati (2001). Five-Point Likert Scale is employed to measure the important of the personal religious values: (1: not at all important, 2 : slightly important, 3 : moderately important, 4: somewhat important, 5: extremely important). These measurements are all reliable since the values of coefficient alpha for both cases, LZS and AIM are above 0.7 as suggested by Nunnally (1978). The former is equivalent to 0.875 while the latter is 0.804 . To ensure that the questionnaire is well answered, the questionnaire is translated into Bahasa Malaysia since all respondents are Malay nation. To analyze the data, the study employs the following three methods of analysis: descriptive, factor analysis and multiple regression analysis (stepwise).

\section{Empirical Findings}

\subsection{The Respondents' Profiles}

Table 1 presents the profile of the entrepreneurs who are recipient of micro credit financing from both institutions, Lembaga Zakat Selangor (LZS) and Amanah Ikhtiar Malaysia (AIM). Generally, the entire respondent for the zakat funds are Muslims because, the Zakat funds were distributed only to the Muslims. Similarly, all the respondents of AIM entrepreneurs are also Muslim. In term of age, the majority of LZS entrepreneurs representing about 25.93 percent fall under the age group of $41-45$ while 34.81 fall under the age of 46-50. Only 6.67 percent of the respondents under this category were less than 35 years old while 8.89 percent above 56. Similarly, the majority of AIM entrepreneurs representing about 22.77 percent fall under the under the age of 41-45 while about 20.30 percent fall under the age of 46-50. In this case, only 12.37 percent of the respondents are below 35 years old while 7.92 percent are above 56 .

For the LZS entrepreneurs, majority of the respondents representing about 65.93 percent are male while the rest were female. On the other hand, the entire respondent for the AIM are female. This is because all the members of AIM are female. Regarding the marital status for the case of LZS entrepreneurs, about 8.15 percent and 65.93 percent of the respondents are single and married respectively. For the case of AIM, about 4.46 percent and 57.92 percent are categorized as single and married respectively. The statistics regarding the education status of the respondents however indicated that, all of them are literate since they all received formal education at least at the primary school. Interestingly, 5 respondents under the group of AIM entrepreneurs have higher education degree. At last, 42.96 percent and 42.57 percent of the respondents for LZS and AIM are involved in trading activities. However, 33.33 and 39.11 percent of LZS entrepreneurs and AIM are involved in service related activities. Some of the services provided including tailor, hotel, motel and so on. Only 18.32 and 23.70 percent of the respondents for LZS and AIM got involved in the production industry. 
Table 1. The profile of respondents

\begin{tabular}{llcc}
\hline Respondents' profile & Items & Entrepreneurs of & Entrepreneurs of \\
AIM & $25(12.37)$ \\
\hline Age & $\leq 35$ & $9(6.67)$ & $37(18.32)$ \\
& $36-40$ & $14(10.37)$ & $46(22.77)$ \\
& $41-45$ & $35(25.93)$ & $41(20.30)$ \\
& $46-50$ & $47(34.81)$ & $37(18.32)$ \\
& $51-55$ & $18(13.33)$ & $16(7.92)$ \\
& $\geq 56$ & $12(8.89)$ & $202(100)$ \\
\hline Gender & Total & $135(100)$ & - \\
& Male & $89(65.93)$ & $202(100)$ \\
& Female & $46(34.07)$ & $202(100)$ \\
\hline Marital status & Total & $135(100)$ & $117(57.92)$ \\
& Married & $89(65.93)$ & $76(37.62)$ \\
& Divorced & $35(25.93)$ & $9(4.46)$ \\
& Unmarried & $11(8.15)$ & $202(100)$ \\
\hline Highest education level & Total & $135(100)$ & $5(2.48)$ \\
& Diploma & - & $121(59.9)$ \\
& Secondary school upper(SPM) & $74(36.63)$ \\
& Secondary school lower(PMR) & $27(20.00)$ & $20.99)$ \\
& Primary school & $74(54.81)$ & $862(100)$ \\
\hline Entrepreneurial activities & Total & $34(25.19)$ & $79(39.11)$ \\
& Trading & $135(100)$ & $37(18.32)$ \\
& Services & $58(42.96)$ & $202(100)$ \\
\hline
\end{tabular}

\subsection{Factor and Multiple Regression Analysis}

In respect to the factors analysis, 24 items was examined. The Kaiser-Meyer-Olkin (KMO) measure of sampling adequacy is 0.825 for the entrepreneurs that are recipient of micro credit financing from Lembaga Zakat Selangor (LZS) while 0.745 for Amanah Ikhtiar Malaysia (AIM)(see Table 2). These values are all significant based on the fact that, they are above the recommended value of 0.6 as proposed by Kaiser (1974). For both cases, the Bartlett's test of sphericity was significant $(\mathrm{p}<0.01)$.

Table 2. The KMO and Bartlett's test for LZS and AIM

\begin{tabular}{lccc}
\hline Description & Entrepreneurs of LZS & Entrepreneurs of AIM \\
\hline Kaiser-Meyer-Olkin Measure of Sampling Adequacy & 0.825 & 0.745 \\
Bartlett's Test of Sphericity & $\mathrm{df}$ & 276 & 276 \\
& Sig. & 0.000 & 0.000 \\
\hline
\end{tabular}

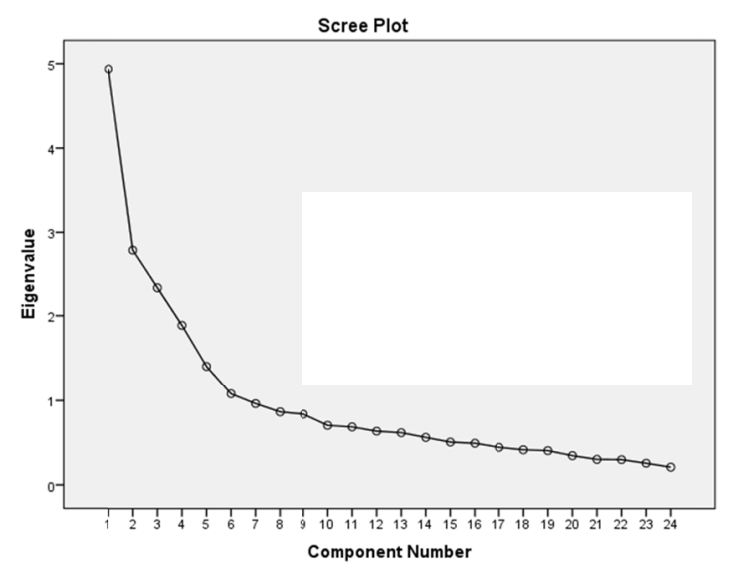

Figure 1. The scree plot for Lembaga Zakat Selangor (LZS) 


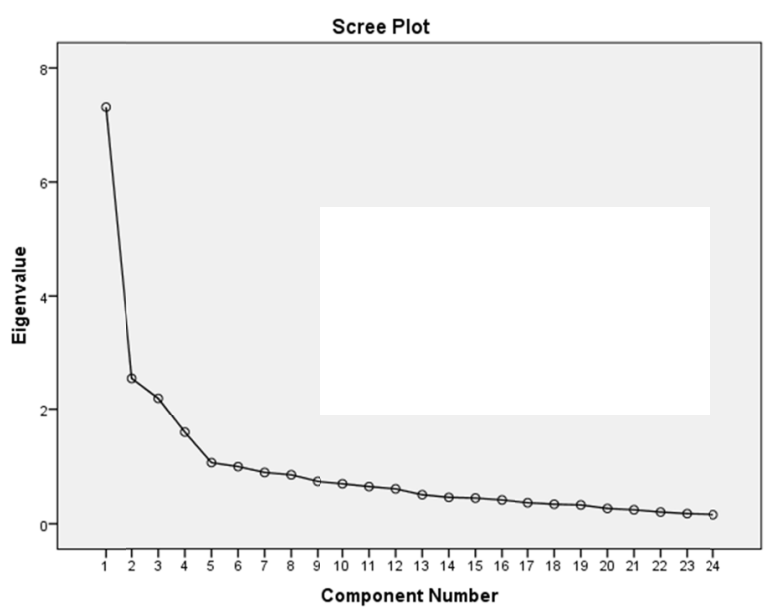

Figure 2. The scree plot for Amanah Ikhtiar Malaysia (AIM)

Furthermore, in the case of LZS, all items were included in factor analysis since the diagonals of the anti-image correlation matrix for each single item were above 0.5 . The communalities values for this group of entrepreneurs were more than 0.3. On the other hand, two items were dropped since the value in the diagonals of the anti-image correlation matrix is less than 0.5 for AIM entrepreneurs. Therefore, the factor analysis was conducted based on the usable items for both cases. In addition, the principle Components Factor Analysis with Varimax rotation was performed. The result of the eigenvalues was greater than 1 . Therefore, only four factors were extracted for both cases (refers to Figure 1 and Figure 2). For entrepreneurs of LZS and AIM, these four factors explained 56.94 percent of the total variance for the former and 50.94 percent for the latter. In order to obtain reliable result, only variables with the factor loading of more than 0.5 were taken into consideration.

Table 3 showed the Principal Components Analysis comprising the religious values for the entrepreneurs of LZS. Four split and interpretable factors namely were identified: sincere and goodness, honesty, truth and right as well as equilibrium and just. All factorable items are retained with the exception of the following two items: 'delivery on time' which fall under honesty factor and also 'organize; influence resources' that are under truth and right. The pattern of factor loading proved strong for the convergent and discriminant validity for the four constructs. Referring to the coefficient alpha, all construct indicated a value that is higher than 0.7 as suggested by Nunnally (1978). Here are the results of the loading: sincere and goodness (0.912), honesty (0.768), truth and right (0.734) and equilibrium and just (0.760). As far as AIM is concerned, four separated and interpretable factors have been identified based on the result of the Principle Components Analysis. The factors as presented by table 4 are: (i) sincere and goodness, (ii) honesty, (iii) truth and right as well as (iv) equilibrium and just. These extracted factors are exactly the same with the LZS. However, no factor was excluded for the case of LZS since their factor loading is more than 0.5 . This result indicated strong significance for the convergent and discriminant validity. The coefficient alphas for all the items are above the required level $(0.7)$ : sincere and goodness $(0.828)$, honesty (0.774), truth and right (0.716) and also equilibrium and just (0.712).

To evaluate the existence of the relationship between these four factors that are employed to represent the personal religious values of the entrepreneurs, the regression analysis method was carried out and the result is presented in Table 5. Regarding the entrepreneurs that received micro credit financing from LZS, the findings indicated that, all factors individually and collectively were significant $(p<0.01)$ to the non-financial performance. However, in the case of AIM entrepreneurs, all factors with the exclusion of truth and right were individually significant $(\mathrm{p}<0.01)$. The collective test however suggested that all the factors were significant with a $\mathrm{p}<0.01$.

Furthermore, the result of the multiple regression stepwise method revealed interesting result. The result indicated significant relationship between personal religious values of entrepreneurs who obtained micro credit financing from LZS with F-value is 27.357 with a p value of less than 0.01 . Although, only three factors were included, in specific: sincere and goodness, honesty as well as just and equilibrium. With the exclusion of the truth and right factor, thus, the model explained 38.5 percent of variance. The model also indicated no issues of multicollinearity problem since the tolerance level and Variance Inflation Factor (VIF) are all in the acceptable range. All the tolerance values are greater than 0.1 while VIF less than 10 . The Durbin-Watson value is 1.845 which is considered closed to 2 ; thus, the independence of residuals assumption did not violate. 
Table 3. Principle components analysis for Lembaga Zakat Selangor (LZS)

\begin{tabular}{llll}
\hline \multicolumn{1}{c}{ Factors } & 1 & 2 & 3 \\
\hline Sincere and goodness & & \\
Introduce others when product is not available & 0.767 & \\
Information and advice available without time restrictions & 0.758 & \\
Change with customer' acknowledgement & 0.756 & \\
Insure customer's satisfaction & 0.745 & \\
Fulfills customers' needs and wants & 0.744 \\
Entertain customers without prejudice & 0.732 \\
Highly passion with customers & 0.729 \\
Service after sale without time constraints & 0.694 \\
Signing contract when company is able to deliver & 0.687 & \\
Payment according to customer's capacity & 0.657 & \\
\hline Honesty & & 0.806 \\
Clear information & & 0.790 \\
Provide good and quality products & & 0.781 \\
Free service to selected customers & & 0.511 \\
True persuasion & & \\
\hline
\end{tabular}

\section{Truth and right}

Equal competition

Strategic alliances with customers

Avoid unlawful income

Reasonable price for same products

Just and equilibrium

Relationship marketing

Customer-oriented services

Customer's first/ focus

High commitment

\section{Coefficient alpha}


Table 4. Principle components analysis for Amanah Ikhtiar Malaysia (AIM)

\begin{tabular}{|c|c|c|c|c|}
\hline Factors & 1 & 2 & 3 & 4 \\
\hline \multicolumn{5}{|l|}{ Sincere and goodness } \\
\hline Signing contract when company is able to deliver & 0.697 & & & \\
\hline Insure customer's satisfaction & 0.686 & & & \\
\hline Change with customer' acknowledgement & 0.668 & & & \\
\hline Highly passion with customers & 0.664 & & & \\
\hline Introduce others when product is not available & 0.662 & & & \\
\hline Fulfills customers' needs and wants & 0.645 & & & \\
\hline Payment according to customer's capacity & 0.637 & & & \\
\hline Entertain customers without prejudice & 0.584 & & & \\
\hline Information and advice available without time restrictions & 0.535 & & & \\
\hline \multicolumn{5}{|l|}{ Honesty } \\
\hline Clear information & & 0.792 & & \\
\hline Provide good and quality products & & 0.723 & & \\
\hline Free service to selected customers & & 0.693 & & \\
\hline Delivery on time & & 0.677 & & \\
\hline True persuasion & & 0.640 & & \\
\hline \multicolumn{5}{|l|}{ Truth and right } \\
\hline Avoid unlawful income & & & 0.786 & \\
\hline Strategic alliances with customers & & & 0.778 & \\
\hline Organize and influence resources & & & 0.768 & \\
\hline Reasonable price for same products & & & 0.559 & \\
\hline \multicolumn{5}{|l|}{ Just and equilibrium } \\
\hline Customer-oriented services & & & & 0.745 \\
\hline Relationship marketing & & & & 0.732 \\
\hline Customer's first/ focus & & & & 0.704 \\
\hline High commitment & & & & 0.652 \\
\hline Coefficient alpha & 0.828 & 0.774 & 0.716 & 0.712 \\
\hline
\end{tabular}

Table 5. Regression analysis (enter) result

\begin{tabular}{lcc}
\hline & LZS & F-value \\
Personal religious values & $20.779^{*}$ & AIM \\
\hline Sincere and goodness & $18.462^{*}$ & $18.144^{*}$ \\
Honesty & $59.070^{*}$ & $26.384^{*}$ \\
Just and equilibrium & $11.900^{*}$ & $18.392^{*}$ \\
Truth and right & $20.718^{*}$ & 3.000 \\
All four factors & & $12.423^{*}$ \\
\hline
\end{tabular}

Notes: * significant at 1 percent.

Similarly, the result of multiple regression analysis based on stepwise method also revealed the significant relationship between personal religious values of entrepreneurs in AIM, F-value: $12.423(p<0.01)$. In this case, the incorporated factors were exactly the same with the entrepreneurs under LZS. The factors are: sincere and 
goodness, honesty and also just and equilibrium. In addition, the model explained 20.1 percent of variance. This model is also free from multicollinearity problem and the independence of residuals assumption is not violated since the Durbin-Watson value was 1.937. Referring to the R-squared, the values for both cases were slightly low due to some reason. Since the focus of the study is mainly on the personal religious values, some other important factors that might contribute to the non-financial performance have been omitted. Factors such as the characteristics of entrepreneurs, social environment, business management and so on might have been excluded.

\section{Discussion}

As indicated in the overall result, personal religious value is found to be significantly related to the non-financial performance of the entrepreneurs in relation to recipient of micro credit from both LZS and AIM. This indicates that, religiosity is an important element of success in entrepreneurial activities. However, 'truth and right' is the only insignificant factor for both groups under. The items under this factor consists of several items including 'equal competition', 'strategic alliances with customers', 'avoid unlawful income' and also 'reasonable price for same products'. The awareness by the entrepreneur to integrate religious values in their activities could potentially enhance the success of the entrepreneurs. This transformation is progressively driven by the better understanding of Islamic teaching gained by entrepreneurs. In line with the status of Malaysia as the hub of Islamic Financial system, more various programs aims at enhancing the religious values among the entrepreneurs has been put in place for the case of LZS and AIM. It is suggested that, other micro credit institutions should emulate this by given high consideration to religious value.

From the side of the provider of micro credit financing like LZS and AIM, the trainings and education programs with the appropriate and suitable modules are especially designed for their entrepreneurs. Such programs are conducted mainly to give better understanding to the entrepreneurs about their roles and responsibilities as a servant of Allah, responsible family life, entrepreneurs, managers and others. Besides that, they are also exposed to the noble values that are important for their personal life as well as entrepreneurial activities. From different angle, the entrepreneurs themselves also put their efforts to improve the existing religious knowledge. Currently, various channel such as media mass, online and offline reading materials, public talks and lectures, the discussion and others to impart such knowledge. This consequently helps to enhance their knowledge because the source of information is within their reach.

Some limitations have however been identified in this study. Despite the fact, that significant relationship between these two variables has been suggested by the result of this study, some other variables that measure personal religious value have been excluded. This is because the items used for measuring religious value in this study have been adopted from the previous studies. Hence, further research that is based on comprehensive personal religious values is suggested. Besides that, the relationship between the personal religious values and the performance of entrepreneurs based on the financial aspect also can be tested. Finally, considering the relevance of religious value in relation to non-financial performance as suggested by the result of this study, it is imperative for the entrepreneur to observe and put them in practice in their activities. Putting into practice will not only benefit the entrepreneur as an individual but to the whole system in the country.

\section{Acknowledgements}

The authors acknowledge the financial support from University of Malaya, Malaysia for this research (Project Number: PS 0352012 A).

\section{References}

Afrane, S. (2002). Impact Assessment of Microfinance Interventions in Ghana and South Africa A Synthesis of Major Impacts and Lessons. Journal of Microfinance, 4(1), 37-58.

Al-Imam, A. H. M. I. M. Al-G. (1998). Ihya 'Ulumuddin (vol. 3). Mesir: Maktabah Misr.

Alowaihan, A. K. (2004). Gender and Business Performance of Kuwait Small Firms: A Comparative Approach. $\begin{array}{llll}\text { International Journal of Commerce \& Management, } 3(4), & 69-82 .\end{array}$ http://dx.doi.org/10.1108/10569210480000185

Amanah Ikhtiar Malaysia. (2012). 2012: Amanah Ikhtiar Malaysia. Retrieved from http://www.aim.gov.my/ cms/index.html

Bhutta, M. K. S., Rana, A. I., \& Asad, U. (2008). Owner Characteristics and Health of SMEs in Pakistan. Journal of Small Business and Enterprise Development, 15(1), 130-149. http://dx.doi.org/10.1108/14626000810850883

Boohene, R., \& Boachie-Mensah, F. O. (2009). Co-Alignment Between Personal Values, Business Strategies and 
Firm Performance of Women-Owned Firms in Ghana. Journal of Business and Enterprise Development, 1(1), 84-101.

Bowen, H. P., \& De Clercq, D. (2008). Institution Context and the Allocation of Entrepreneurial Effort. Journal of International Business Studies, 39(4), 747-767. http://dx.doi.org/10.1057/palgrave.jibs.8400343

Carter, S., \& Shaw, E. (2006). Women's business ownership: Recent research and policy developments. UK: Small Business Service.

Chusmir, L. H., \& Kobre, C. S. (1998). Religion and Attitudes Toward Word: A New Look at an Old Question. Journal of Organizational Behavior, 9, 251-262.

Clark, J. W., \& Dawson, L. E. (1996). Personal Religiousness and Ethical Judgments: An Empirical Analysis. Journal of Business Ethics, 15, 339-372. http://dx.doi.org/10.1007/BF00382959

Cullan, J. B., \& Parboteeah, K. P. (2008). Multinational Management: A Strategic Approach. Mason, OH: South-Western Publishing.

Cunningham, J. B., \& Lischeron, J. (1991). Defining Entrepreneurship. Journal of Small Business Management, $29(1), 450-461$.

Dafna, K. (2008). Managerial Performance and Business Success: Gender Differences in Canadian and Israeli Entrepreneurs. Journal of Enterprising Communities: People and Places in the Global Economy, 2(4), 300-331. http://dx.doi.org/10.1108/17506200810913890

Dess, G. G., \& Robinson, R. B. (1984). Measuring Organizational Performance in the Absence of Objective Measure: The Case of Privately-Held Firm and Conglomerate Business Unit. Strategic Management Journal, 5, 265-273. http://dx.doi.org/10.1002/smj.4250050306

Farah, A. A. N., Rashidah, A. R., \& Normah, O. (2012). Zakat and Poverty Alleviation: Roles of Zakat Institutions in Malaysia. International Journal of Arts and Commerce, 1(7), 61-72.

Gadenne, D. (1998). Critical Success Factors for Small Business: An Inter-Industry Comparison. International Small Business Journal, 17(1), 36-57. http://dx.doi.org/10.1177/0266242698171002

Garengo, P., Biazzo, S., \& Bititci, U. S. (2005). Performance Measurement Systems in SMEs: A Review for a Research Agenda. International Journal of Management Reviews, 7(1), 25-47. http://dx.doi.org/10.1111/j.1468-2370.2005.00105.x

Haber, S., \& Reichel, A. (2005). Identifying Performance Measures of Small Ventures-The Case of Tourism Industry. Journal of Small Business Management, 43(3), 257-283. http://dx.doi.org/10.1111/j.1540-627X.2005.00137.x

Hamdino, H. P., Fadzim, O., \& Wan, S. W. H. (2012). The Important of Monitoring and Entrepreneurship Concept as Future Direction of Microfinance in Malaysia: Case Study in the State of Selangor. Journal of Global Entrepreneurship, 3(1), 1-25.

Harada, N. (2003). Who Success as an Entrepreneur? An Analysis of the Post-Entry Performance of New Firms in Japan. Japan and World Economy, 15(2), 211-222.

Hietalahti, J., \& Linden, M. (2006). Socio-Economic Impacts of Microfinance and Repayment Performance: A Case Study of Small Enterprise Foundation, South Africa. Progress in Development Studies, 6(3), 201-210. http://dx.doi.org/10.1191/1464993406ps138oa

Hunt, S. D., \& Vitell, S. J. (1986). A General Theory of Marketing Ethics. Journal of Macromarketing, 8(Spring), 5-16. http://dx.doi.org/10.1177/027614678600600103

Kaiser, H. F. (1974). An Index of Factorial Simplicity. Psychometrika, 39, 31-36. http://dx.doi.org/10.1007/BF02291575

Kenji, K. (2002). The Relationship Between Private and Public Financing for Small Business. The Japanese Economy, 30(2), 3-28.

Khandker, S. R. (2003). Microfinance and Poverty: Evidence Using Panel Data from Bangladesh. Policy Research Working Paper, No 2945, World Bank Washington, D.C. http://dx.doi.org/10.1093/wber/lhi008

Kolodinsky, J. (1999). Consumer Satisfaction With a Managed Health Care Plan. The Journal of Consumer Affairs, 33(2), 223-236. http://dx.doi.org/10.1111/j.1745-6606.1999.tb00068.x

Kotey, B., \& Meredith, G. G. (1997). Relationships among Owner/Manager Personal Values, Business 
Strategies, and Enterprise Performance. Journal of Small Business Management, 35(2), 37-64.

Kriger, M. P., \& Hanson, B. J. (1999). A Value-Based Paradigm for Creating Truly Healthy Organizations. $\begin{array}{llll}\text { Journal of Organizational Change } & \text { Management, } & \text { 12(4), }\end{array}$ http://dx.doi.org/10.1108/09534819910282144

Kuzilwa, J. (2005). The Role of Credit for Small Business Success: A Study of the National Entrepreneurship Development Fund in Tanzania. The Journal of Entrepreneurship, 14(2), 131-161. http://dx.doi.org/10.1177/097135570501400204

Lembaga, Z. S. (2013). Lembaga Zakat Selangor: Majlis Agama Islam Selangor. Retrieved from http://www.e-zakat.com.my/

Machan, T. R. (1999). Entrepreneurship and Ethics. International Journal of Social Economics, 26(5), 596-608. http://dx.doi.org/10.1108/03068299910216103

Markman, G., \& Baron, R. (2003). Person-Entrepreneurship Fit: Why Some People Are More Successful as Entrepreneurs Than Others. Human Resource Management Review, 13(2), 281-301. http://dx.doi.org/10.1016/S1053-4822(03)00018-4

Masuo, D., Fong, G., Yanagida, J., \& Cabal, C. (2001). Factors Associated with Business and Family Success: A Comparison of Single Manager and Duel Manager Family Business Households. Journal of Family and Economics Issues, 22(1), 55-73.

Minniti, M. (2008). The Role of Government Policy on Entrepreneurial Activity: Productive, Unproductive or $\begin{array}{llll}\text { Destructive? Entrepreneurship Theory and Practice, 32(5), } & \text { 779-790. }\end{array}$ http://dx.doi.org/10.1111/j.1540-6520.2008.00255.x

Muhammad, A. S. (2012). The Impact of Socio-Economic Factors on Small Business Success. Malaysia Journal Society and Space, 8(1), 24-29.

Murphy, G. B., Trailer, J. W., \& Hill, R. C. (1996). Measuring Performance in Entrepreneurship Research. Journal of Business Research, 36(1), 15-23. http://dx.doi.org/10.1016/0148-2963(95)00159-X

Norma, M. S., \& Jarita, D. (2010). Determinants of Economic Performance of Micro-Credit Client and Prospect of Islamic Microfinance in Malaysia. ISRA International Journal of Islamic Finance, 2(1), 113-130.

Nunnally, J. C. (1978). Psychometric theory (2nd ed.). New York: McGraw-Hill.

Park, A., \& Ren, C. (2001). Microfinance with Chinese Characteristics. World Development, 29(1), 39-62. http://dx.doi.org/10.1016/S0305-750X(00)00087-5

Peterson, R. A., Albaum, G., Merunka, D., Munuera, J. L., \& Smith, S. M. (2010). Effects of Nationality, Gender and Religiosity on Business-Related Ethicality. Journal of Business Ethics, 96, 573-587. http://dx.doi.org/10.1007/s10551-010-0485-2

Pollitt, D. (2004). Hard Listening and Straight Talking: The Aker Approach. Human Resource Management, 12(5), 19-22.

Raduan, C. R., Kumar, N., \& Lim, L. Y. (2006). Entrepreneurs Success Factors and Escalation of Small and Medium-Sized Enterprises in Malaysia. Journal of Sciences, 2(3), 78-80.

Rahman, S., Rafiq, R. B., \& Momen, M. A. (2009). Impact of Microfinance Programs on Higher Income Borrowers: Evidence from Bangladesh. International Business \& Economics Research Journal, 8(2).

Rhodes, C., \& Butler, J. S. (2004). Understanding Self-Perceptions of Business Performance: An Examination of Black American Entrepreneurs. Journal of Developmental Entrepreneurship, 9(1), 55-71.

Rohaizat, B., \& Suzilawati, K. (2001). The Effects of Entrepreneurs' Personal Religious Values and Business Performance in Information Technology Industry. Journal of Enterprising Culture, 11(1), 437- 448.

Sagie, A. (1988). Measurement of Religiosity and Work Obligations Among Israeli Youth. The Journal of Social Psychology, 133(4), 529-537. http://dx.doi.org/10.1080/00224545.1993.9712178

Sarder, J. H., Ghosh, D., \& Rose, P. (1997). The Importance of Support Services to Small Enterprises in Bangladesh. Journal of Small Business Management, 35(2), 26-36.

Scheepers, P., \& Van der Silk, F. (1998). Religion and Attitudes on Moral Issues: Effects of Individual, Spouse and Parental Characteristics. Journal of Scientific Study of Religion, 374(4), 678-688. http://dx.doi.org/10.2307/1388149 
Siddiqui, A. (1997). Ethics in Islam: Key Concepts and Contemporary Challenges. Journal of Moral Education, 26(4), 423-431. http://dx.doi.org/10.1080/0305724970260403

Syed, W. H. N. (2011). Critical Success and Failure Factors of Entrepreneurial Organizations: Study of SMEs in Bahawalpur. Journal of Public Administration and Governance, 1(2), 17-22.

Thapa, A. (2007). Micro-Enterprise and Household Income. The Journal of Nepalese Business Studies, 4(1), $110-118$.

Wijewardena, H., Nanayakkara, G., \& De Zoysa, A. (2008). The Owner/ Manager's Mentality and the Financial Performance of SMEs. Journal of Small Business and Enterprise Development, 15(1), 150-161. http://dx.doi.org/10.1108/14626000810850892

Wimalasari, P., \& Abdul. (1996). An Empirical Study of Moral Reasoning Among Managers in Singapore. Journal of Business Ethics, 15, 1331-1341. http://dx.doi.org/10.1007/BF00411818

Zafir, M. M., \& Fazilah, M. H. (2011). Entrepreneurial Success: An Exploratory Study Among Entrepreneurs. International Journal of Business and Management, 6(1), 116-125.

Zinger, J. T., LeBrasseur, R., \& Zanibbi, L. R. (2001). Factors Influencing Early Stage Performance in Canadian Microenterprises. Journal of Developmental Entrepreneurship, 6(2), 129-150. 